10.21867/KjK/2016.3.6.

\title{
KÖZRENDÉSZET ÉS MAGÁNRENDÉSZET - ÚJ SZÖVETSÉGBEN
}

\section{Tóth Judit ${ }^{1}$}

Ha a közjószágok közé soroljuk a közterületek rendjét és a közbiztonságot, akkor aligha fogadható el, hogy azokból sokakat kirekesszenek, mások pedig élősködő módon finanszíroztassák magántulajdonuk, befektetésük vagy szabadidős tevékenységük védelmét az adófizetökkel. A növekvő társadalmi egyenlötlenségek ebben az újfajta szimbiózisban is éreztetik hatásukat, de miként?

Durvább megfogalmazásban jönnek a magánhadseregek, magánzsoldosok, akik a megfelelő oligarchák szándékát gyorsan megvalósítják, aztán majd a jogi helyzetet ahhoz hozzáigazítják. Nem a szomszédos Ukrajnáról vagy a távolabbi Oroszországról beszélhetünk csupán, hanem a Fradi Security kopaszairól, akik segítettek a választási iroda előtt a népszavazási kezdeményezés be/nem/adásában. ${ }^{2}$ „Ha jól következtetünk, akkor izgalmas idők következnek. Már csak azért is, mert egyelöre nem tudható, hogy az ukrán, vagy az orosz modell irányába indulnak el az események. Az ukrán modellben a politikai, gazdasági erős emberek is nekiállnak hadsereget toborozni. Ha erre az útra lépnénk, izgalmas, Csák Máté-s hangulatú időkre kell számítani, vad portyázásokkal, hajnali csatazajjal, és erősen fellendülő biztonságiör-iparral. Az orosz modellben viszont csak az erös központi hatalomnak van magánhadserege, szóval nincsenek utcai harcok, sem megostromolt gyárak. A kézi irányítású erőszakszerv csak néha jelenik meg, hogy kiosszon egy-egy kokit és sallert, ha döcögős folyamatot kell sínre tenni, eltévelyedett szövetségest meggyőzni, vagy túl beszédes embert jobb belátásra bírni.” Nálunk vajon mi következik?

A magánbiztonság a közbiztonság kiegészitője, így szerepe járulékos. Ugyanakkor a magánbiztonság változóban van, a kockázatok, a személyek mozgása és az áruk határokon átlépő szállítása egyre növekszik, miközben az emberek vágynak a biztonságra a közösségi színtereken. Ám mindenhová nem ér el a közfinanszírozású biztonsági rendszer. A hálózatosodás, az integráció és a közösségi kapcsolatok erősödése aztán újabb változásokat hoz magával a mentalistásban is. Talán ez utóbbi része, hogy átadják a hagyományos közbiztonsági tennivalók egy részét magáncégeknek, és ez a jövőben bővülni fog, amely megköveteli a két szektor közötti párbeszéd intézményesítését a vásárlók, megrendelők, hatóságok, közpolitikát alakítók között, nemzeti és európai szinten egyaránt. A kérdés tehát az, hogyan lehet egy biztonságosabb Európát teremteni magas minőségü szolgáltatásokkal a rendelkezésre álló forrásokból egy nyilvános dialógus révén, minden érintett bevonásával. Az Északi országok együttmüködése ehhez adhat támpontokat - javasolta Lars O Molin, az Almega Biztonsági Cég elnöke még 2008-ban a régió magánbiztonsági szektoráról szóló Jelentés $^{3}$ bevezetőjében, hiszen 1901-ben a szektor Dániában született meg. Azóta ezek a

\footnotetext{
${ }^{1}$ Tóth Judit CSc., tszv. egyetemi docens, SZTE ÁJK.

${ }^{2}$ FöLDES András: Izgalmas idők jönnek, toborozzon magánhadsereget ön is!, Index.hu

${ }^{3}$ Private and public security in the Nordic countries, Almega.
} 
jelenségek még jobban láthatóvá váltak, pedig már 2008-ban Magyarország azon tíz európai állam között volt, amelyekben a magánbiztonsági vállalkozások létszáma, a piaci nyitás következtésben is nagyobb volt, mint az állami biztonsági-rendészeti szerveké. Ezek az országok főként az új uniós tagállamok voltak, és a magánbiztonsági vállalkozások főleg a vagyonőrzés, pénzszállítás, beléptetés ellenőrzése, személyvédelem terén törtek előre.

\section{Rendészeti tevékenységet ellátó szervezetek és alkalmazotti állomány Európában}

\begin{tabular}{|c|c|c|c|c|c|}
\hline State & Population & $\begin{array}{l}\text { Police force / } \\
\text { ratio }\end{array}$ & $\begin{array}{c}\text { Security force/ } \\
\text { ratio }\end{array}$ & $\begin{array}{l}\text { Security } \\
\text { companies }\end{array}$ & Personnel \\
\hline Austria & 8300000 & $1: 415$ & $1: 830$ & 200 & 10000 \\
\hline Belgium & 10403951 & $1: 267$ & $1: 821$ & 196 & 12673 \\
\hline Bosnia-Herzegovina & 4590310 & - & $1: 590$ & 41 & 2000 \\
\hline Bulgaria & 7262675 & $1: 155$ & $1: 124$ & 1029 & 58703 \\
\hline Croatia & 4491543 & $1: 236$ & $1: 280$ & 246 & 16000 \\
\hline Cyprus & 792604 & $1: 258$ & $1: 466$ & 60 & 1700 \\
\hline Czech Republic & 10220911 & $1: 222$ & $1: 198$ & 5629 & 51542 \\
\hline Denmark & 5400000 & $1: 368$ & $1: 1010$ & 338 & 5250 \\
\hline Estonia & 1400000 & $1: 419$ & $1: 224$ & 242 & 6000 \\
\hline Finland & 5244749 & $1: 697$ & $1: 517$ & 200 & 10000 \\
\hline France & 64057790 & $1: 256$ & $1: 427$ & 4800 & 159000 \\
\hline Germany & 82369548 & $1: 330$ & $1: 476$ & 3500 & 177000 \\
\hline Greece & 10722816 & $1: 214$ & $1: 428$ & 1000 & 30000 \\
\hline Hungary & 10000000 & $1: 250$ & $1: 125$ & 11304 & 105121 \\
\hline Ireland & 4329925 & $1: 353$ & $1: 412$ & 840 & 17500 \\
\hline Italy & 59131287 & $1: 139$ & $1: 304$ & 965 & 49166 \\
\hline Latvia & 2300000 & $1: 217$ & $1: 230$ & 300 & 10000 \\
\hline Lithuania & 3565205 & $1: 180$ & $1: 360$ & 67 & 10000 \\
\hline Luxembourg & 462000 & $1: 294$ & $1: 210$ & 10 & 2200 \\
\hline Macedonia & 2061315 & - & $1: 368$ & 152 & 5600 \\
\hline Malta & 410000 & $1: 215$ & $1: 256$ & 6 & 700 \\
\hline Netherlands & 16645313 & $1: 314$ & $1: 555$ & 320 & 33158 \\
\hline Norway & 4644457 & $1: 567$ & $1: 387$ & 257 & 12000 \\
\hline Poland & 38600000 & $1: 386$ & $1: 234$ & 3600 & 165000 \\
\hline Portugal & 10676910 & $1: 228$ & $1: 275$ & 113 & 38874 \\
\hline Romania & 22246862 & $1: 393$ & $1: 235$ & 1099 & 92000 \\
\hline Serbia & 7400000 & $1: 218$ & $1: 264$ & 158 & 28000 \\
\hline Slovakia & 5455407 & $1: 251$ & $1: 314$ & 1730 & 17200 \\
\hline Slovenia & 2000000 & $1: 267$ & $1: 444$ & 100 & 6211 \\
\hline Spain & 40491052 & $1: 182$ & $1: 488$ & 1219 & 83000 \\
\hline Sweden & 9045389 & $1: 502$ & $1: 670$ & 250 & 13500 \\
\hline Switzerland & 7581520 & $1: 473$ & $1: 879$ & 464 & 13075 \\
\hline Turkey & 71892807 & $1: 496$ & $1: 453$ & 937 & 35263 \\
\hline United Kingdom & 60943912 & $1: 431$ & $1: 244$ & 1500 & 250000 \\
\hline
\end{tabular}

Forrás: Private and public security in the Nordic countries. Confederation of European Security Services, CoESS General Secretariat - ALMEGA Private Security, 2009

Az európai szabályozási megoldások alapján az országokat három csoportba sorolhatjuk. A legszigorúbb hatósági engedélyezési, ellenőrzési és a müködésre vonatkozó részletes szabályozás megléte az egyik. A másik csoport a szinte alig szabályozottaké, ide tartoznak a skandináv államok, mert ott az erős képzésben és professzionalizmusban jobban hisznek, míg a kettő között több ország szabályozása helyezhető el. Az biztos, hogy mindegyikben legalább a tevékenységhez hatósági bejelentés kell, és az engedélyező/regisztráló szerv az igazságügyi 
vagy a belügyi tárcához tartozó szerv, illetve a regionális önkormányzat. Az ilyen biztonsági cégeknél a vállalkozónak, dolgozónak a munkához meghatározott életkor, büntetlen előélet szükséges, de több tagállamban követelmény lehet az állampolgárság, vagy bizonyos egészségi állapot (pl. Portugáliában, Romániában, Szlovákiában), a megfelelő nyelvismeret (pl. a baszk, a katalán), a katonai szolgálat teljesítése (Görögországban, Spanyolországban) és a megfelelő testmagasság. Akad példa az összeférhetetlenségi, kettős jogállást tilalmazó szabályra (pl. Belgiumban, Hollandiában) illetve a közelmúltban a közszektorban tevékenykedők kizárására. Sok országban a köz/vagy a magánszektor által szervezett vizsgát kell tenni (Belgium, Spanyolország, Németország), és lehetnek minimum követelmények a cégvezetőkre is.

Az osztályozás másik útja attól függ, hogy a biztonsági cégek és az állami hatóságok, rendészek közt milyen az együttmüködés, van-e egyáltalán, helyi szinten vagy szituatív módon (pl. büncselekmények bejelentése, akció keretében segítségnyújtás), vagy az intézményesült-e (pl. megállapodásokat kötöttek az országos szintű szervekkel), illetve csak bizonyos területeken él (pl. közlekedés, vadászat, horgászat). Az idézett Jelentés kimutatta, hogy általában hiányos az állami ellenőrzés a magánbiztonsági vállalkozások müködését illetően, és ennek egyik oka a széttagolt hatósági rendszer, mivel több állami szerv is jogosult a kontrollra, ellenőrzésre és persze a szabályozásra, bírságolásra, engedélyek visszavonására. Az ipar, a kereskedelem, a pénzügyi szektor, a közlekedés és más szolgáltatások, ha igénylik müködésükhöz a megfelelő biztonságot, úgy a magáncégek fejlődni fognak, közben talán átveszik a skandináv országoktól, hogy a biztonsági cégek minél több szakmai és munkaügyi, képzési kérdést tartalmazó kollektív (ágazati) szerződéseket kössenek, csökkentve a szektorban dolgozók kiszolgáltatottságát. A sharing economy ${ }^{4}$ elterjedésével nem csak az UBER taxiját ${ }^{5}$, de a legközelebb lévő biztonsági öröket, pénzszállítókat, személyi kísérőket is házhoz rendelhetjük egy ügyes netes alkalmazással? A szabályozás a biztonsági szabványosítás, egységes minimumok megalkotása és elfogadása felé halad, az $\mathrm{EU}^{6}$ is szorgalmazni fogja a két szféra közti rendszeres párbeszédet, bejáratott együttmüködést alakítva a nyilvánosan gyakran látogatott helyeken (bevásárló központok, sportesemények, pályaudvarok, kikötők, repülőterek) a rendelkezésre álló adatok és eszközök, képzési és tréningezési lehetőségek megosztásával. Ugyanakkor a magáncégek hálózatosodása, regionális együttműködése is folytatódik. Bár az európai országokban nő a rendőri létszám, a hagyományosan éjszaka (is) múködő biztonsági vállalkozásokra nagy szükség lesz a tulajdon, az élet védelme és a biztonságérzet, a társadalmi bizalom javítása érdekében, és ezt talán a biztonság-és közpolitikát alakítók is felismerik. Ez azonban nem járhat a közterületek rendjét és a közbiztonságot védelmező közösségi (állami, önkormányzati) erőfeszítések csökkentésével, hiszen egyenlő hozzáférést kell nyújtani e közjószághoz mindenkinek (pl. hajléktalannak, munkanélkülinek, idősnek, külföldieknek).

\footnotetext{
${ }^{4}$ What is the Sharing Economy?

${ }^{5}$ KANYUK Petra Ágnes: Útikalauz az Uber galaxisában magyar stopposoknak - összefoglaló a hazai események alakulásáról, Közjavak.hu, 2016.

${ }^{6}$ Communication from the Commission to the European Parliament, the Council, the European Economic and Social Committee and the Committee of the Regions, $\operatorname{COM}(2015) 185$ final.
} 
Az Alaptörvény $\mathrm{O}$ cikke szerint mindenki felelös önmagáért, és a $\mathrm{V}$. cikk alapján joga van törvényben meghatározottak szerint, a személye és a tulajdona ellen intézett vagy az ezeket közvetlenül fenyegető jogtalan támadás elhárításához, továbbá éppen a saját magának a zsarnoksággal szembeni megóvása érdekében arra, hogy ha valakinek a tevékenysége a hatalom erőszakos megszerzésére, gyakorlására vagy kizárólagos birtoklására irányulna, úgy törvényes úton ezzel szemben fellépjen. (C cikk (2) bekezdés) Ez a megközelítés az egyéni biztonságot és annak minden legitim eszközét - így a magánbiztonsági cégek szolgáltatásainak igénybe vételét is - elsőként említi, azaz elsődlegesnek tekinti, kiegészítve azzal, hogy a magánbiztonsági cégek is hivatkozhatnak a vállalkozás jogára a XII. cikk szerint. Ugyanakkor megkötés, hogy a tulajdonjogot gyakorolni csak a szociális, gazdasági következmények belátásával, azaz a társadalmi felelősségre hivatkozó korlátozással (közérdeküség tesztje) lehet a XIII. cikk értelmében. Mivel egyre több szektorban az állami (nemzeti) tulajdon meghatározó mértékü, a közérdeket aligha tekinti magára nézve megszorításnak az állami vagyonkezelő, amely definíciószerüen eleve a közjót szolgálja. Ám a jogszabályok és az Alaptörvény (az ugyanis nem jogszabály) érvényesítése érdekében kényszert alkalmazni csak az állam jogosult (C cikk (3) bekezdés), tehát a magánbiztonság megteremtéséhez az nem alkalmazható, és az alapvető jogok védelme az állam elsőrendü kötelezettsége (I. cikk (1) bekezdés). Nehéz megfejteni, hogy az önvédelem és az állam (akár erőt is alkalmazó) jogvédelmi kötelezettsége milyen viszonyban van egymással, valamint a biztonsághoz, a méltósághoz, az egészséghez való alapjog érvényesítését célzó garanciákkal, ha mindegyik elsődleges. A kapcsolatot színezi, hogy az önvédelem és a tulajdonvédelem a jogtalan támadás elhárítására vagy a zsarnok ellen csak erőszakmentesen történhet, és kényszert alkalmazni legfeljebb jogos védelmi helyzetben lehet. Továbbá, az állam az elsőrendü kötelezettségét teljesítve, konkuráló alapjogok ütközésekor vagy alkotmányos érték - például ilyen lehet a közrend, a közbiztonság védelme, a nemzetbiztonsági érdek megóvása érdekében legitim módon korlátozhat alapjogot az arányosság-szükségesség betartásával, a tulajdonjog esetében pedig a közérdekre is hivatkozhat. Vajon az önvédelemhez való jogot is korlátozhatja, ha az egyben személyes kötelezettség? A tulajdonés személyi védelmet gyakorló, a megrendelői kívánságokat teljesíteni akaró cégekre miként vonatkozik a tulajdon társadalmi kötöttsége?

Ezeket a kérdéseket a gyakorlatban kell megválaszolnia a rendörségnek alapfeladatait teljesítve, azaz a közbiztonság és a közrend védelme során, míg a nemzetbiztonsági szolgálatoknak a törvényes rend (ez nyilván különbözik az előző kettőtől) és a nemzetbiztonsági érdekek érvényesítésekor (46. cikk). A rendőrségnek annyival nehezebb a dolga, hogy nem elég saját dolgozói közt ezt tisztázni, mint a nemzetbiztonsági szolgálatoknál, hanem (hallgatólagos) megegyezésre kell jutnia ebben a többi rendészeti szervvel, a magánbiztonsági vállalkozásokkal és civil szervezetekkel is. A tisztázást nehezíti, sőt további kérdéseket vet fel, hogy a rendészeti feladatok és szervek köre folyamatosan bővül, azaz egészen eltérő képzettségü, feladatkörü emberek számára adnak felhatalmazást kényszerítő eszközök alkalmazására, hatósági intézkedések megtételére. Ennek vizsgálata azonban már egy következő írás tárgya lehet... 